\title{
Purine Dysfunction in Cells from Patients with Adenosine Deaminase Deficiency
}

\author{
PAUL J. BENKE ${ }^{(37)}$ AND DAVID DITTMAR \\ Mailman Center and the Department of Pediatrics, University of Miami School of Medicine, Miami, Florida, USA
}

\section{Extract}

Conversion of adenosine to inosine is decreased in adenosine deaminase (ADA)-deficient fibroblasts at all concentrations of adenosine tested. Adenosine is not differentially toxic to ADA-deficient fibroblasts except at very high $\left(5 \times 10^{-4}-1 \times 10^{-3} \mathrm{M}\right)$ adenosine levels. Conversion of $\left[{ }^{14} \mathrm{C}\right]$ adenosine to GTP is not decreased in ADA-deficient cells compared with control cell strains. Adenosine conversion to ATP is the same as that in mutant cells except at high nonphysiologic concentrations, at which it is slightly decreased in ADA-deficient fibroblasts. This effect is probably not related to the biochemical pathology of ADA-deficient lymphocytes in vivo.

Uridine, a pyrimidine compound, "rescues" control cells from the effects of adenosine toxicity, as previously reported, but it has no protective effect on ADA-deficient fibroblasts. This suggests that uridine will have no therapeutic role in the treatment of the ADAdeficient form of severe combined immunodeficiency (SCID) disease.

\section{Speculation}

The purine base, hypoxanthine, may be necessary for normal immunologic responses.

Severe combined immunodeficiency is an uncommon but devastating disorder characterized by decreased ability to fight infection and low or absent circulatory $\mathrm{T}$ and $\mathrm{B}$ lymphocytes. Patients frequently die unless competent immunologic cells are successfully transplanted. It has been known since 1972 that some of these patients have almost complete absence of $\operatorname{ADA}$ activity $(5,13)$. In a recent summary of the experience in the United States, Meuwissen et al. (16) found that 13 of 22 patients with SCID had ADA deficiency. ADA-deficient patients may be clinically and pathologically distinguished from others with SCID because they have characteristic radiologic abnormalities of the skelton and the presence of Hassall's corpuscles in the thymus $(16,26)$. Normal immunocompetent cells are produced in ADA-deficient patients for a period of time (16). Although one unusual African boy has been found with low erythrocyte ADA activity (12), no immunologic abnormalities were noted. His lymphocyte enzyme activity was found to be $10 \%$ of control (6) and may be high enough to sustain grossly normal immunologic function.

The locus for ADA activity is on chromosome 20 (25), and this gene controls the enzyme activity of all ADA isoenzymes (8). Isoenzymes change during immunologic stimulation (9) as enzyme activity increases 2- to 3-fold (7). There are varying amounts of residual enzyme activity in enzyme-deficient patients (1). Little is known, however, of the role ADA plays in the normal biochemistry of cells. Because decreased ADA activity is almost certainly causally related to immunologic disease in enzyme-deficient patients, we have examined cultured skin fibroblasts in vitro for possible consequences of loss of ADA activity.

\section{METHODS}

Human fibroblast cell cultures were established from punch skin biopsies obtained from the forearm and grown in Gibco F12 medium (28) with $15 \%$ fetal calf serum and $1 \%$ penicillin-streptomycin solution. Three adenosine deaminase-deficient cell strains were obtained from other investigators (29). Cell cultures were monitored for mycoplasma by cultivation in BBL Mycoplasma broth base with enrichment (30) and none was found during the course of the investigation.

Fibroblasts were trypsinized, counted on a Coulter electronic particle counter (31), and then plated at a density of 10,000 cells/cc in wells in a tissue culture plate (32). Test medium was added after 20-24 hr. Fifteen percent horse serum (28) was used for toxicity studies because it does not contain endogenous ADA activity (22).

Fibroblasts were harvested by trypsinization just after reaching confluency. They were washed three times in phosphate-buffered saline before incubation with $\left[{ }^{14} \mathrm{C}\right]$ adenosine (33). General reaction conditions and procedures were similar to those previously described (3). After the incubation of cells with radioactive adenosine, the reaction was stopped by the addition of $25 \mu 14.2 \mathrm{M}$ $\mathrm{HCl}$ and the mixture was neutralized with $25 \mu 14.42 \mathrm{M} \mathrm{KOH}$ and centrifuged. Twenty microliters of the supernatant were spotted on Whatman no. 3MM paper previously soaked in $0.05 \mathrm{M}$ sodium borate, $\mathrm{pH}$ 9.0. Twenty nanomoles of carrier inosine, xanthine, guanosine, hypoxanthine, guanine, adenine, and adenosine were applied to the same spot and high voltage electrophoresis was carried out at 2,250 V for $2 \mathrm{hr}$. Spots were located under ultraviolet light, cut out, and counted in a Packard liquid scintillation counter with toluene-diphenyloxazole (PPO)-p-bis[2-(5-phenyloxazalyl)]-benzene (POPOP).

Nucleotides were chromatographed by anion exchange on a thinlayer; PEI-cellulose plate (33) as previously described (17) after a preparatory rinse in $200 \mathrm{ml} \mathrm{MeOH}-\mathrm{H}_{2} \mathrm{O}(1: 1)$ for $20 \mathrm{~min}$ to remove purine bases, nucleosides, and salts (20). Nucleotide spots were located, cut out, and counted as described above.

\section{RESULTS}

\section{$\left[{ }^{14} \mathrm{C}\right]$ ADENOSINE INCUBATION}

Figure 1 shows the incubation of control cells with $\left[{ }^{14} \mathrm{C}\right]$ adenosine with time. Metabolites of adenosine reach a peak level at 60 $\mathrm{min}$, and adenosine levels decrease further at later time points. It can be seen in Figures 1, 2, and 3 that more $\left[{ }^{14} \mathrm{C}\right]$ adenosine is converted to inosine than to adenine nucleotides in control cells at concentrations above $2 \times 10^{-6} \mathrm{M}$. Inosine to ATP incorporation ratios were $2: 4$ at 2,3 , and $4 \times 10^{-6} \mathrm{M}$ adenosine. This ratio increased to 10 at $4 \times 10^{-6} \mathrm{M}$ adenosine. Figure 2 shows that $\left[{ }^{14} \mathrm{C}\right]$ adenosine conversion to inosine and hypoxanthine by the adenosine deaminase reaction is greatly decreased at all levels of adenosine in ADA-deficient cells. $\left[{ }^{14} \mathrm{C}\right]$ Adenosine incorporation into GTP as shown in Figure 3 is the same in control and 


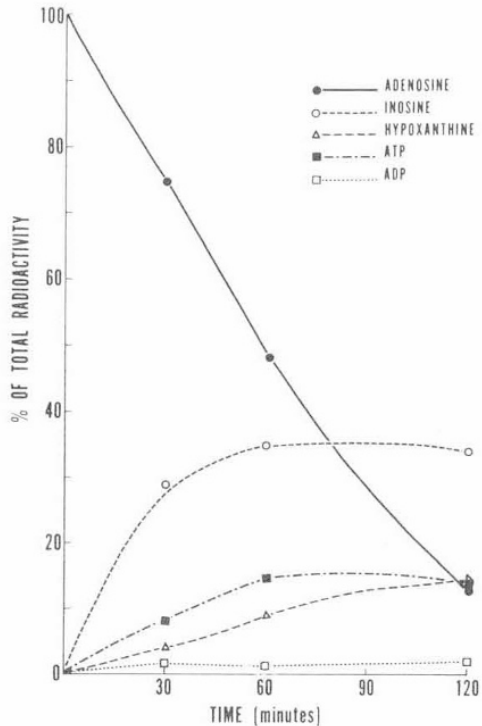

Fig. 1. Time sequence of adenosine metabolism by control human fibroblasts. Cells were incubated with $4 \times 10^{-6} \mathrm{M}\left[{ }^{14} \mathrm{C}\right]$ adenosine. Purine metabolites were separated by thin layer chromatography and high voltage chromatography.

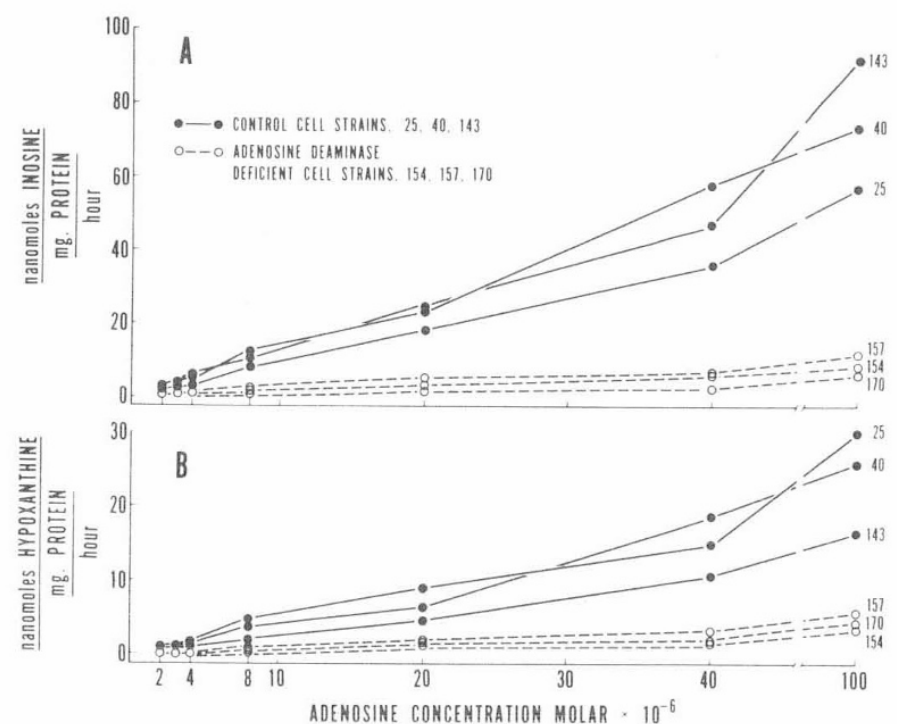

Fig. 2. Conversion of adenosine to inosine $(A)$ and hypoxanthine $(B)$ in control and mutant cell strains at different concentrations of adenosine. Incubation was for $1 \mathrm{hr}$ at $37^{\circ}$. Each point is the average of two determinations.

ADA-deficient cells. Adenosine incorporation to ATP and ADP, as shown in Figure 4, is similar in control and ADA-deficient cell strains except at concentrations of adenosine greater than $10^{-4} \mathrm{M}$. $\left[{ }^{14} \mathrm{C}\right]$ Adenosine conversion to ATP at high adenosine concentrations was consistently decreased by about $20 \%$ in ADA-deficient cells at concentrations above $3 \times 10^{-4} \mathrm{M}$ within any particular experiment, and was statistically significant. However, when data from five experiments were combined, as shown in Figure 5, there was sufficient variation in results so that the differences between mutant and normal cells were not statistically significant. Adenosine levels required to get decreased levels of ATP formed in ADA-deficient cells, as shown in Figure 5, are 10-fold greater than that found toxic to cell growth in Figure 6. It is important to note that ATP formation from $\left[{ }^{14} \mathrm{C}\right]$ adenosine is not increased in ADA-deficient cells. In other experiments not shown, 4, 6 , and $8 \times$
$10^{-4} \mathrm{M}$ adenosine does not inhibit the conversion of $1 \times 10^{-4} \mathrm{M}$ $\left[{ }^{14} \mathrm{C}\right]$ adenine to ATP. Thus, the decreased $\left[{ }^{14} \mathrm{C}\right]$ adenosine conversion to ATP found within an experiment at very high adenosine concentrations in ADA-deficient cells may be due to substrate inhibition of adenosine on the enzyme adenosine kinase, and adenosine pool sizes may be larger in these cells.

Incorporation of $\left[{ }^{14} \mathrm{C}\right]$ adenosine into ATP and ADP, as expressed as an ATP:ADP ratio, was also the same in control and ADA-deficient cells. ATP:ADP ratios were $3: 1$ in control and mutant cells at low adenosine concentrations of $2-4 \times 10^{-6} \mathrm{M}$. ATP:ADP ratios were higher at higher adenosine concentrations, but were still approximately the same in control and ADA-deficient cell strains.

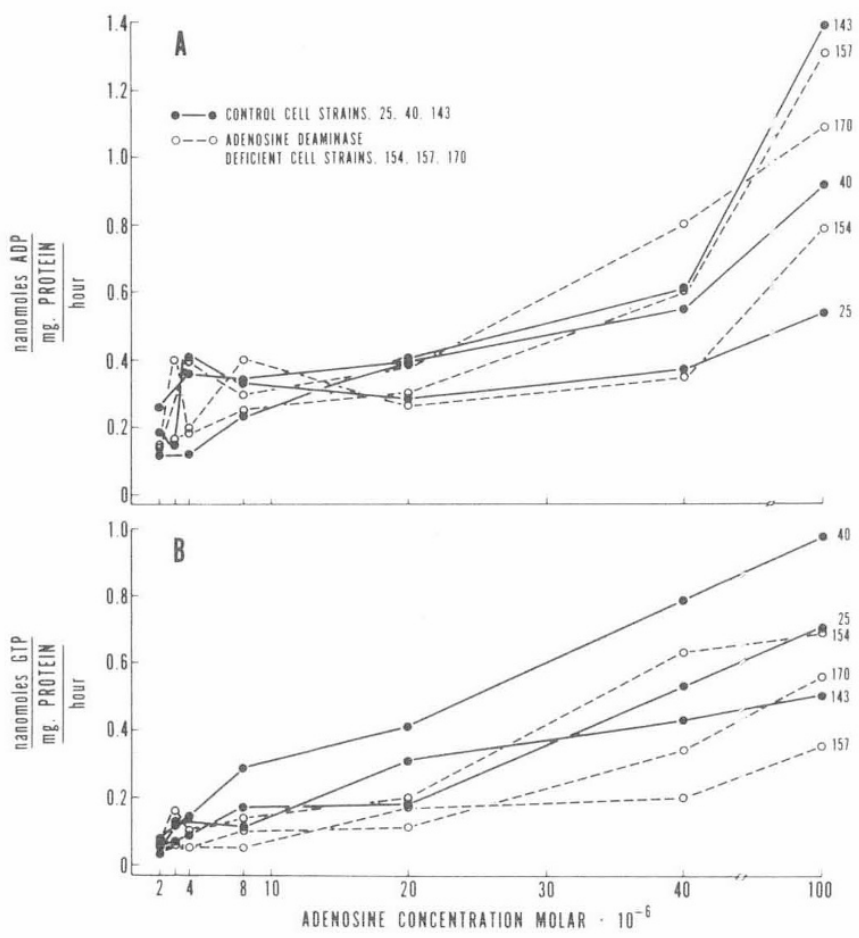

Fig. 3. Conversion of adenosine to $\operatorname{ADP}(A)$ and GTP $(B)$ in control and adenosine deaminase-deficient cell strains. Conditions were the same as Figure 2.

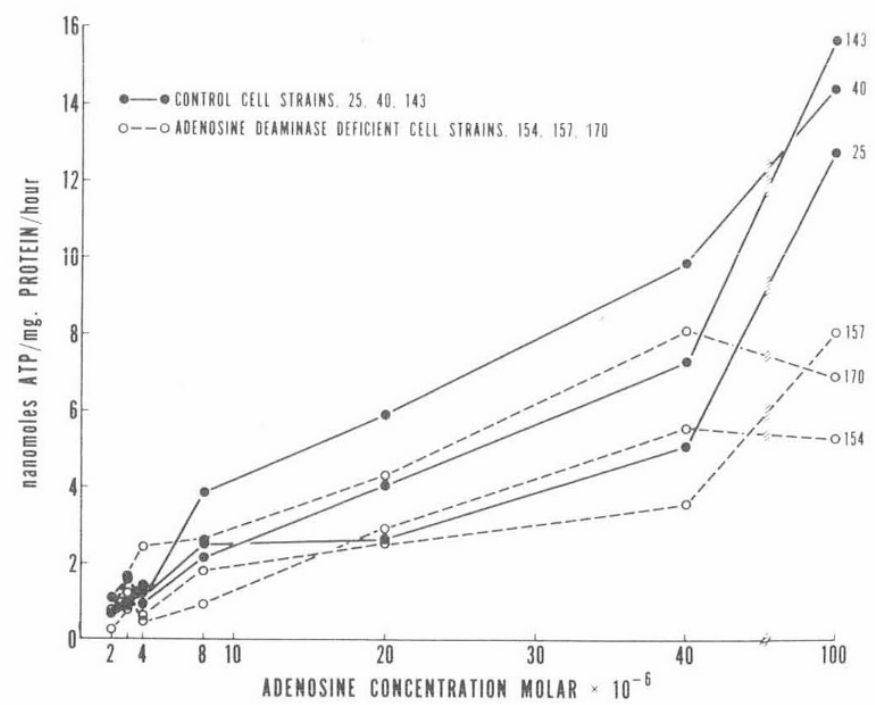

Fig. 4. Conversion of adenosine to ATP in control and adenosine deaminase-deficient cell strains. Conditions were the same as Figure 2. 


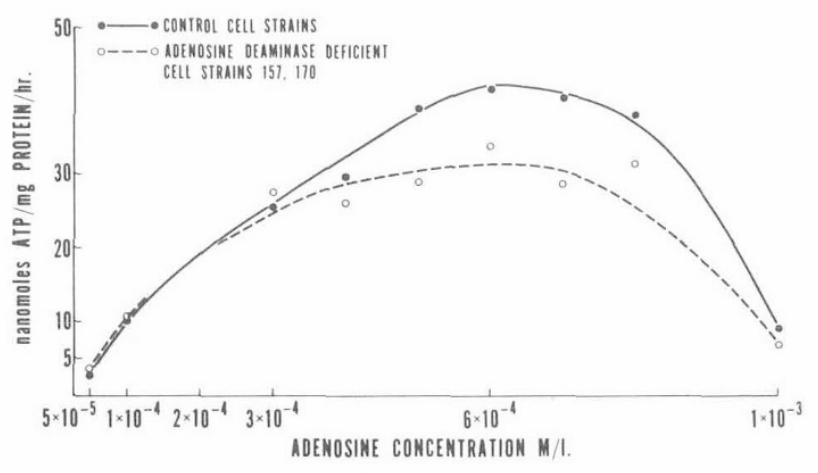

Fig. 5. Conversion of adenosine to ATP in control and adenosine deaminase-deficient cell strains. Conditions were the same as in Figure 2, and each point is the average of five determinations.

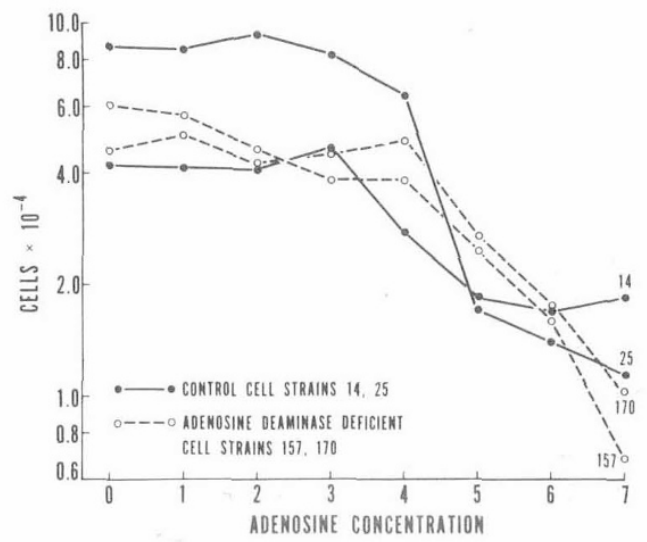

Fig. 6. Adenosine toxicity in control and adenosine deaminase-deficient fibroblasts. Cells, $0.1 \times 10^{5}$, were plated in microtiter plates with $\mathrm{F} 10$ media without hypoxanthine and with $15 \%$ horse serum. Fresh media containing a 3-fold stepwise increase in adenosine from concentration 1 $\left(6.2 \times 10^{-6} \mathrm{M}\right)$ to concentration $6\left(1.5 \times 10^{-3} \mathrm{M}\right)$ were added to the culture after $24 \mathrm{hr}$, and every other day until the cells were counted on day 7 .

Conversion of $\left[{ }^{14} \mathrm{C}\right]$ adenosine to $\left[{ }^{14} \mathrm{C}\right] \mathrm{GTP}$ is the same in ADA-deficient cells and control cells. Thus, conversion to inosine is probably not involved, and GTP synthesis from $\left[{ }^{14} \mathrm{C}\right]$ adenosine takes place from AMP, IMP, XMP, and GMP, as shown in Figure 8. Only $0.6-0.8 \%$ of $\left[{ }^{14} \mathrm{C}\right]$ adenosine is converted to GTP in control and ADA-deficient cells at $2-4 \times 10^{-6} \mathrm{M}$ adenosine, and this decreased to $0.2-0.4 \%$ at $2 \times 10^{-5} \mathrm{M}$ adenosine and $0.1 \%$ at 1 $\times 10^{-4} \mathrm{M}$ in both cell strains. If ADA deficiency interrupts an important purine interconversion pathway it does not appear to be the synthesis of guanine nucleotides from adenosine. Little adenosine is converted to GTP in control and mutant cells.

\section{TOXICITY STUDIES}

Adenosine could be more toxic to the growth of ADA-deficient fibroblasts than control cells because mutant cells lack the enzyme which converts adenosine to the less toxic metabolite, inosine. Figure 6 shows data from one of several experiments which suggest that adenosine is equally toxic to ADA-deficient and control cell strains. We have decided that control and ADA-deficient cell strains demonstrate similar toxicity when exposed to adenosine because the slopes of the toxicity curves are the same. Adenosine primarily inhibits control cells from dividing rather than killing them or causing them to detach. ADA-deficient cell strains were not more sensitive to adenosine in the culture medium in at least two experiments with each cell strain. However, in some experiments, the control cell strain has more cells at the highest adenosine concentration noted. In these experiments, the control cells have not divided but have remained attached to the plate, whereas ADA-deficient cells have detached and there are fewer cells than originally plated (Figures 6 and 7). Thus, adenosine is not more toxic to growing control and mutant cells, but does kill nondividing ADA-deficient cells at very high $\left(5 \times 10^{-4}-1 \times 10^{-3}\right.$ M) adenosine levels. In experiments not shown, the use of fetal calf serum instead of horse serum in toxicity studies greatly decreased the toxicity of adenosine for control and ADA-deficient cell strains. It might be expected that adenosine is more toxic to rapidly proliferating cells, but the rate of cell division is about $24 \mathrm{hr}$ in both lymphocytes and fibroblasts.

Ishii and Green (11) have found that cells exposed to toxic amounts of adenosine may be "rescued" with uridine, an end product of pyrimidine metabolism. We have confirmed the "rescue" effect of uridine in control cells as shown in Figure 7, but do not find in similar experiments shown in Figure 7 that uridine has this effect in ADA-deficient fibroblast cell strains. This suggests that uridine may play no role in the therapy of ADA deficiency.

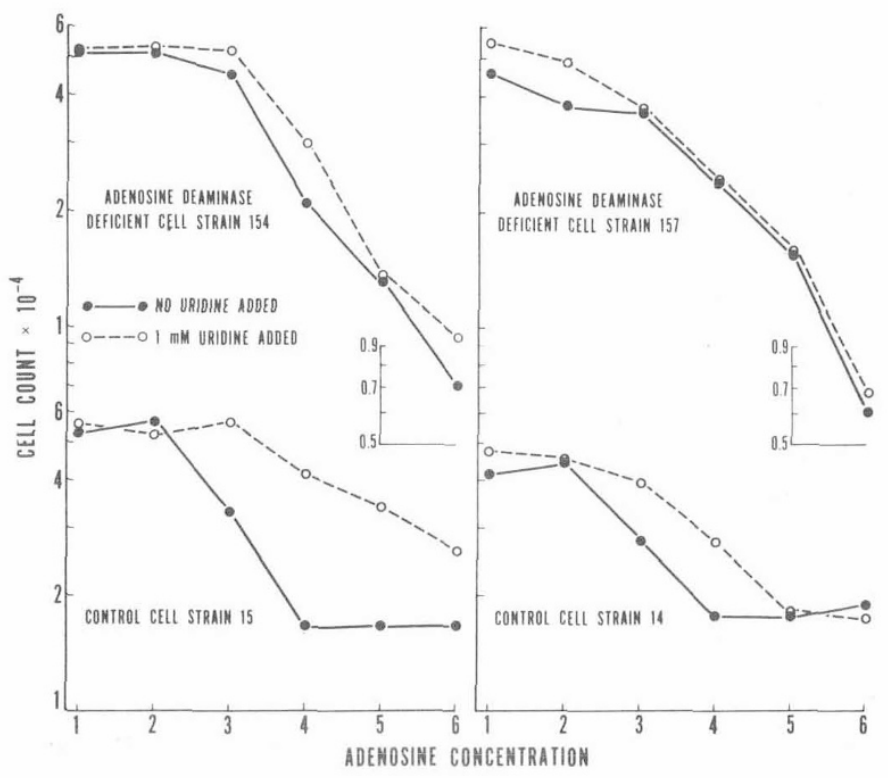

Fig. 7. Effect of uridine on adenosine toxicity in control and adenosine deaminase-deficient fibroblasts. Conditons were the same as in Figure 6, except that $1 \mathrm{mM}$ uridine was added to the media containing different levels of adenosine for feeding $24 \mathrm{hr}$ after plating, and adenosine concentration was increased 3-fold from concentration $1\left(6.8 \times 10^{-7} \mathrm{M}\right)$ to concentration $7\left(5 \times 10^{-4} \mathrm{M}\right)$.

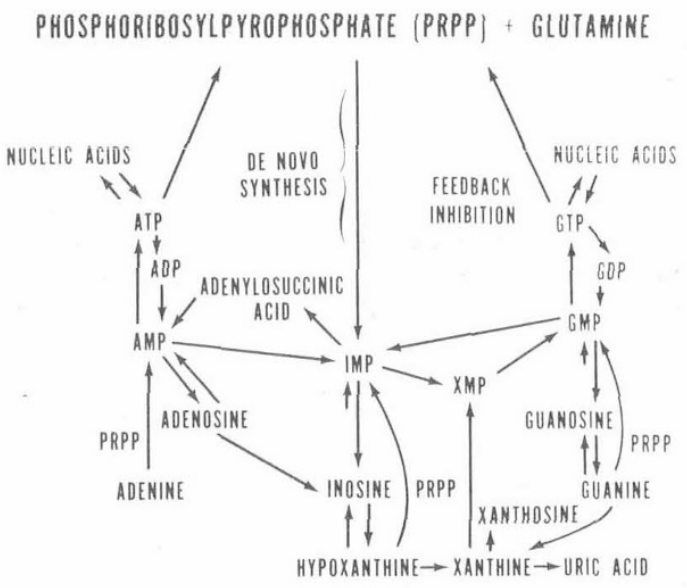

Fig. 8. Pathways of purine metabolism. Adenosine deaminase converts adenosine to inosine. 


\section{DISCUSSION}

The experiments described test two hypotheses of the biochemical pathology of cells with ADA deficiency. The first is whether adenosine is more toxic to cells which lack ADA activity than control cell strains. This was not found in three ADA-deficient fibroblast cell strains tested on several occasions (Fig. 6). An adenosine metabolite such as ATP may be responsible for the toxic effects of adenosine since cells which lack adenosine kinase activity are 70 times less sensitive to adenosine toxicity (11). Addition of adenosine to phytohemagglutinin (PHA)-stimulated lymphocytes inhibits the PHA response and DNA synthesis (6). Conversion of adenosine to adenine nucleotides is the same at physiologic adenosine levels in mutant and control cells as shown in Figures 3 and 4. This can be correlated with the finding that ADA-deficient cells are not more toxic to the effect of adenosine except at high adenosine concentrations, at which adenosine causes ADA-deficient cells to detach. Our data does not support a toxic mechanism as primary in the biochemical dysfunction of the ADA-deficient form of SCID.

Adenosine may be toxic to cells because nucleotides of adenosine either inhibit the activity of orotate monophosphate (OMP) pyrophosphorylase or decrease the amount of phosphoribosyl pyrophosphate available to this enzyme (6). This inhibits pyrimidine biosynthesis by $80 \%$ (6) and decreases pyrimidine nucleotide pools by $90 \%$ (11). Adenosine effects are prevented in control cells by providing uridine as a pyrimidine source (6). It has been predicted that uridine would have a favorable effect on the ADA enzyme-deficient form of SCID (11). The data shown in Figure 7 suggest that this may not be the case, since uridine protects control cells from adenosine toxicity as expected, but does not protect ADA-deficient cells. The mechanism for this failure is not clear. Even if adenosine nucleotide pools were larger in ADA-deficient cells than control cells, leading to the inhibition of synthesis of OMP pyrophosphorylase, exogenous uridine should be able to overcome this effect. The failure of uridine correction could be explained by a similar nucleoside transport system for adenosine and uridine, and expanded adenosine pool sizes in mutant cells which limit uridine transport at all exogenous uridine levels. Uridine does not increase the response of ADA enzyme-deficient lymphocytes to phytohemagglutin (19). These combined results suggest that uridine is not likely to be of therapeutic benefit to enzyme-deficient patients.

A second hypothesis of cellular dysfunction is that loss of ADA activity interrupts an important purine salvage pathway. Meyskens and Williams (17) have found that radioactive adenosine is converted to AMP by the enzyme adenosine kinase at low $\left(10^{-6}\right.$ $\mathrm{M})$ concentrations in human erythrocytes and largely converted to inosine by adenosine deaminase at high $\left(4 \times 10^{-5} \mathrm{M}\right)$ concentrations. We find that more adenosine is converted to inosine than ATP in cultured fibroblasts at levels of adenosine as low as $2 \times$ $10^{-6} \mathrm{M}$. If an important purine pathway is lost in mutant cells, it might be expected that it would be the synthesis of guanine nucleotides from adenosine. This synthesis could be more important in lymphocytes than other cells, since bone marrow cells depend upon sources such as the liver for preformed purines (14). Figure 3 shows that the synthesis of GTP from adenosine is the same in control and ADA-deficient cells. These pathways are shown in Figure 8. Likewise, ATP, ADP, and AMP synthesis from adenosine is the same in control and ADA-deficient cell strains, except at adenosine levels well above those which cause toxicity, as shown in Figure 5, where adenosine incorporation into ATP is slightly less in mutant cells. Once AMP is formed, it is not easily dephosphorylated to adenosine in cultured human cells. At least $12 \%$ of radioactive adenine is found in inosine during $\left[{ }^{14} \mathrm{C}\right]$ adenine incubation, and little of the radiolabel is found in adenosine (21), suggesting that the pathway, AMP to IMP to inosine, is active. Adenosine incorporation data in our radiochemical experiments do not measure adenine nucleotide pool sizes. Adenine nucleotide pool sizes are increased in adenosine-treated normal lymphocytes (11).

It is necessary to work with fibroblasts because it has not yet been possible to experiment with sufficient quantities of lymphocytes from ADA-deficient patients. Also, a lymphocytoid cell line from an enzyme-deficient patient has not yet been established. Establishment of lymphocytoid cell lines from ADA patients may be required to test whether ( $I$ ) ADA-deficient lymphocytes are more sensitive to adenosine than ADA-deficient fibroblasts; (2) adenosine interferes with any important immunologic function other than cell division; or (3) large amounts of adenosine are generated in the immune response. Tissue differences in purine nucleotide interconversion and enzymes do exist. For example, IMP metabolism in cultured human fibroblasts is primarily to adenine nucleotides (21), whereas it is primarily to guanine nucleotides in Ehrlich ascites tumor cells (3). Similarly, at low concentrations, the metabolism of adenosine is to AMP in human red cells (17), whereas it may be to inosine in rat heart (15). We have obtained preliminary data which suggests that lymphocytes are like red cells (17) and unlike fibroblasts in that they convert more adenosine to ATP than inosine at low adenosine concentrations. Previous lymphocyte toxicity data (11) compared with the fibroblast data in Figures 6 and 8 suggest that lymphocytes may be slightly more sensitive to the toxic effects of adenosine than fibroblasts, although adenosine is an inhibitor of lymphocytemediated cytotoxicity (27) at adenosine levels (ID (I0 $_{0}$ of .15 mM) which are also toxic to fibroblast cell growth (shown in Figures 6 and 7). Fibroblast cell division and quantitative enzyme pathways may differ enough from that found in lymphocyte cells that few conclusions should be transferred from our work with fibroblasts to lymphocyte cell function.

Patients with ADA deficiency have gradual loss of immunocompetent cells, and this could be due to loss of a purine source required for immunologic responses. It can be seen in Figure 2 that ADA-deficient fibroblasts have decreased conversion of adenosine to inosine and hypoxanthine at all concentrations of adenosine tested. Loss of ADA activity would interrupt an important pathway in lymphocytes if hypoxanthine were needed for the immune response. Little work has been done on purine sources required for PHA stimulation, but almost all media used in the work on PHA effects on human lymphocytes, since the original description of the technique (18), have used media containing purines. It has been known for some time that lymphocytes have almost no capacity for synthesis of purine from simple precursors (23), but readily incorporate preformed purines into nucleic acids $(23,24)$. Nevertheless, the most popular lymphocyte culture medias, the RMPI series, do not have a purine source (29). This may explain why lymphocytes do not grow at low population densities; a variant form of "metabolic cooperation" previously found in purine metabolism in cultured fibroblasts (2) may be taking place at high lymphocyte population densities to insure adequate purine nucleotides among the cells in the culture.

Nucleoside phosphorylase is an enzyme one step removed from ADA in purine interconversion pathways, and it converts inosine to hypoxanthine (Fig. 8). That decreased levels of intracellular hypoxanthine may be associated with impairment of the immune response is further suggested by the recent association of decreased nucleoside phosphorylase activity in a patient with defective $\mathrm{T}$ cell function but normal B cell function (4). It is not clear why the clinical expression in this patient differs slightly from patients with ADA deficiency, but it would be expected that hypoxanthine levels are decreased, and levels of inosine, a relatively nontoxic compound, are increased in the cells of this patient. Our data show that decreased levels of hypoxanthine are generated from adenosine in ADA-deficient fibroblast cells, but do not answer the question of whether this is important for immunologic function in lymphocytes. Hypoxanthine could be administered to ADA-deficient patients, along with allopurinol, a xanthine oxidase inhibitor, needed to prevent the formation and renal precipitation of the 
insoluble purine metabolite, xanthine. If lymphocyte cell levels of hypoxanthine are decreased, this purine may improve the immune response. It may be worth giving hypoxanthine to PHA-treated, ADA-deficient lymphocytes in vitro to test this possibility.

\section{SUMMARY}

ADA-deficient fibroblasts are not more susceptible to the toxic effects of adenosine except at high levels $\left(5 \times 10^{-4}-1 \times 10^{-3} \mathrm{M}\right)$, at which ADA-deficient cells detached from the dish and control cells did not divide. ADA-deficient fibroblasts have normal ability to convert $\left[{ }^{14} \mathrm{C}\right]$ adenosine to GTP and adenine nucleotides, except at high adenosine concentrations, at which ATP synthesis from adenosine is slightly decreased. There is decreased conversion of $\left[{ }^{14} \mathrm{C}\right]$ adenosine to inosine and hypoxanthine at all concentrations of adenosine tested in ADA-deficient cells.

\section{REFERENCES AND NOTES}

1. Chen, S., Scott, C. R., and Swedberg, K. R.: Heterogeneity for adenosine deaminase deficiency: Expression of the enzyme in cultured skin fibroblasts and amniotic fluid cells. Amer. J. Human Genet., 27: 46 (1975).

2. Cox, R. P., Krauss, M. R., Balis, M. E., and Dancis, J.: Evidence for transfer of enzyme product as the basis of metabolic cooperation between tissue culture fibroblasts of Lesch-Nyhan disease and normal cells. Proc. Natl. Acad. Sci. U.S.A., 67: 1573 (1970).

3. Crabtree, G. W., and Henderson, J. F.: Rate-limiting steps in the interconversion of purine ribonucleotides in Ehrlich ascites tumor cells in vitro. Cancer Res. 31: 985 (1971).

4. Giblett, E. R., Ammand, A. J., Ward, D. W., Sandman, R., and Diamond, L, K.: Nucleoside phosphorylase deficiency in a child with severely defective $T$ cell immunity and normal B cell immunity. Lancet, $i$ : 1010 (1975).

5. Giblett, E. R., Anderson, J. E., Cohen, F., Pollara, B., and Meuwissen, H. J.: Adenosine-deaminase deficiency in two patients with severely impaired cellular immunity. Lancet, ii: 1067 (1972).

6. Green, H., and Chan, T.: Pyrimidine starvation by adenosine in fibroblasts and lymphoid cells: Role of adenosine deaminase. Science, 182: 836 (1973).

7. Hall, J. G.: Adenosine deaminase activity in lymphoid cells during antibody production. Aust. J. Exp. Biol., 41: 73 (1963).

8. Hirschhorn, R.: Conversion of human erythrocyte adenosine deaminase activity to different tissue-specific to isozymes. J. Clin. Invest., 55: 661 (1975).

9. Hirschhorn, R., and Levytska, V.: Alterations in isoenzymes of adenosine deaminase during stimulation of human peripheral blood lymphocytes. Cell Immunol. 12: 387 (1974).

10. Hirschhorn, R., Levytska, V., Pollara, B., and Meuwissen, H. J.: Nature New Biol., 246: 200 (1973).

11. Ishii, K., and Green, H.: Lethality of adenosine for cultured mammalion cells by interferance with pyrimidine biosynthesis. J. Cell. Sci., 13: 429 (1973).

12. Jenkins, T.: Red blood cell adenosine deaminase deficiency in a "healthy"! Kung individual. Lancet, ii: 736 (1973).

13. Knudsen, B. B., and Dissing, J.: Adenosine deaminase deficiency in a child with severe combined immunodeficiency. Clin. Genet., 4: 344 (1973).

14. Lajtha, L. G., and Vane, J. R.: Dependence of bone marrow cells on the liver for purine supply. Nature, 182: 181 (1958).
15. McGuire, M. H., Lukas, M. C., and Rettie, J. F.: Adenine nucleotide salvage synthesis in the rat heart: Pathways of adenosine salvage. Biochim. Biophys. Acta, 262: 108 (1972).

16. Meuwissen, H. J., Pollara, B., and Pickering, R. J.: Combined immuno deficiency disease associated with adenosine deaminase deficiency. J. Pediat., 86: 169 (1975).

17. Meyskens, F. L., and Williams, H. E.: Adenosine metabolism in human erythrocytes. Biochim. Biophys. Acta, 240: 170 (1971).

18. Nowell, P. C.: An initiator of mitosis in cultures of normal human leukocytes. Cancer Res., 20: 462 (1960).

19. Parkman, R., Gelfand, E. W., Rosen, F. S., Sanderson, A., and Hirschhorn, R.: Severe combined immunodeficiency and adenosine deaminase deficiency. New Engl. J. Med., 292: 714 (1975).

20. Randerath, K., and Randerath, F. J.: Ion-exchange chromatography of nucleotides on poly-(ethyleneimine)-cellulose thin layers. J. Chromatogr., 16: 111 (1974).

21. Raivio, K. O., and Seegmiller, J. E.: Adenine, hypoxanthine and guanine metabolism in fibroblasts from normal individuals and from patients with hypoxanthine phosphoribosyl-transferase deficiency. Biochim. Biophys. Acta, 299: 273 (1973).

22. Schwartz, P. M., Shipman, C., and Drach, J. C.: Extensively heat-inactivated calf serum: A tissue culture media supplement devoid of adenosine deaminase activity. In Vitro, 9: 385 (1974).

23. Scott, J. L.: Human leukocyte metabolism in vitro. I. Incorporation of adenine-8-C ${ }^{14}$ and formate- $\mathrm{C}^{14}$ into the nucleic acids of leukemic leukocytes. J. Clin. Invest., 41: 67 (1962).

24. Shapira, J., Bornstein, I., Wells, W., and Winzler, R. J.: Metabolism of human leukocytes in vitro. IV. Incorporation and interconversion of adenine and guanine. Cancer Res., 21: 265 (1961).

25. Tischfield, J. A., Creagan, R. P., Nichols, E. A., and Ruddle, F. H.: Assignment of a gene for adenosine deaminase to human chromosome 20. Human Hered., 24: I (1974).

26. Yount, J., Nichols, P., Ochs, H. D., Hammer, S. P., Scott, C. R., Chen, S., Giblett, E. R., and Wedgwood, R. J.: Absence of erythrocyte adenosine deaminase associated with severe combined immunodeficiency. J. Pediat., 84: 173 (1974).

27. Wolberg, G., Zimmerman, T. P., Hiemstra, K., Winston, M., and Chu, L. C.: Adenosine inhibition of lymphocyte-mediated cytolysis: Possible role of cyclic adenosine monophosphate. Science, 187: 957 (1975).

28. Grand Island Biochemicals, Long Island, N. Y.

29. Adenosine deaminase-deficient cell strains 154, 157, and 170 were obtained from Dr. R. Cox, New York, N. Y., Dr. H. Goldman of the Repository for Mutant Cell Strains, Montreal Children's Hospital (originally from Dr. F. Rosen, Boston, Mass.), and Dr. C. R. Scott, Seattle, Wash., respectively. We thank them for this assistance.

30. Baltimore Biological Laboratory (BBL), Cockeysville, Md

31. Coulter Electronics, Hialeah, Fla.

32. Limbro Co., New Haven, Conn.

33. New England Nuclear Corp., Boston, Mass.

34. Baker Chemical Co., Phillipsburg, N. J.

35. This work was supported by grants from the National Foundation-March of Dimes.

36. Paul J. Benke is a Kennedy Scholar for Child Development.

37. Requests for reprints should be addressed to: P. J. Benke, M. D., Mailman Center, University of Miami School of Medicine, Miami, Fla. 33152 (USA).

38. Accepted for publication January 14, 1976. 